\title{
1. Appropriateness of Gastroscopy: Dyspepsia $^{1}$
}

\author{
F. Froehlich*, M. Bochud**, J.-J. Gonvers*, R.W. Dubois***, J.-P. Vader**, V. Wietlisbach***, B. Burnand** \\ * Policlinique Médicale Universitaire, Lausanne, Switzerland \\ ** Institut Universitaire de Médecine Sociale et Préventive, Lausanne. Suvitzerland \\ *** Protocare Sciences, Santa Monica, USA
}

\section{Introduction}

Dyspepsia is a very common set of clinical symptoms. Clear-cut scientific evidence of the effectiveness of diagnostic schemes is unavailable for most clinical situations related to dyspepsia. For this and other reasons, practice patterns vary widely. The development of explicit detailed criteria of appropriateness of use of endoscopy is an attempt to produce best available evidence (based on a validated panel process and expert judgment) where better evidence is lacking, with the aim to assist the clinician in daily decision making,

In November 1998, a multidisciplinary European expert panel convened in Lausanne, Switzerland, to discuss and develop criteria for the appropriate use of gastrointestinal endoscopy, a widely-used procedure, regarded as highly accurate and safe. The RAND appropriateness method was chosen for this purpose, because it allows the development of appropriateness criteria based on published evidence and supplemented by explicit expert opinion. A detailed description of the RAND appropriateness method, including the literature search process [I], and of the whole process, as well as the global results of the panel [2], are published as separate articles in this issue of the Journal. The literature review was based on a systematic search of Medline, Embase and the Cochrane Library conducted up to the end of 1997 and completed with some key articles published in 1998. Updating and revision of the literature review is currently ongoing.

This article presents a literature review on dyspepsia, that was provided to the panelists to study and comment prior to the panel meeting to support their ratings of appropriateness of use of upper gastrointestinal endoscopy. This article furthermore presents an overview of the main panel results

Findoscopy 1999: 31 (8) 579 - 595

6. Georg Thieme Verlag Stuttgan - New York

ISSN 0013-726X related to dyspepsia and a summary of published evidence and panel-based appropriateness criteria.

\section{Literature Review}

\section{Definition of Dyspepsia}

Evaluation of dyspepsia is reportedly the most frequent indication for upper endoscopy referrals [3]. Although commonly used by clinicians, the term dyspepsia has not been uniformly defined, thus complicating the critical review of the literature relating dyspepsia to patient outcome. To permit standardisation of terminology and a better understanding of dyspepsia, a 1988 working group [4] established the following classification: Dyspepsia is either organic (that is, due to specific lesions such as peptic ulcer, esophagitis, gastric carcinoma or other pathologies) or non-organic (upper abdominal discomfort for which no focal lesion is responsible). Four dyspepsia sub-groups were defined, based on predominant symptoms and potential etiologies [4.5]: ulcer-like, reflux-like, dysmotility-like, non-specific. An international working party consensus [6] defined dyspepsia as episodic or persistent abdominal symptoms, often related to food intake, which patients or physicians believe to be due to disorders of the proximal portion of the digestive tract. At the Maastricht consensus conference in 1997. a workshop on dyspepsia [7] adopted the following definition of dyspepsia: pain or discomfort in the upper abdomen, including nausea, vomiting, early satiety, epigastric fullness and regurgitation but not heartburn or dysphagia.

The development of a reliable tool providing a global measurement scale for severity of dyspepsia is a difficult task, due to the difficulty in defining dyspepsia uniformly. The Glasgow dyspepsia severity score, a global measurement scale for dyspepsia, seems to be a valid, reproducible tool but no definition of dyspepsia is given and no distinction is made between the different forms of dyspepsia [8].

\footnotetext{
The European Panel on Appropriateness of Giastrointestinal Endoxcopy (EPAGE, Lausanne, Switzerland)
} 
Table 1 Prevalence of endoscopic changes in dyspeptic patients

\begin{tabular}{|c|c|c|c|c|c|c|}
\hline & $\begin{array}{l}\text { Heikkinen } 1995 \\
n(\%)\end{array}$ & $\begin{array}{l}\text { Sobala } 1991 \\
n(\%)\end{array}$ & $\begin{array}{l}\text { Patel } 1994 \\
n(\%)\end{array}$ & $\begin{array}{l}\text { Vaira } 1997 \\
n(\%)\end{array}$ & $\begin{array}{l}\text { Vaira } 1997 \\
n(\%)\end{array}$ & $\begin{array}{l}\text { Mansi 199: } \\
n(\%)\end{array}$ \\
\hline Normal & $254(63)$ & $169(58)$ & $75(63)$ & $807 \cdot(25)$ & $359(23)$ & $630(28)$ \\
\hline Gastritis/erosions & $0(0)$ & $16(5)$ & $O(0)$ & $1214(38)$ & $757(47)$ & $783(35)$ \\
\hline Duodenitis & $9(2)$ & $17(6)$ & $12(10)$ & $430(13)$ & $214(13)$ & $328(14)$ \\
\hline Gastric ulcer & $17(4)$ & $17(6)$ & $4(3)$ & $119(4)$ & $55(3)$ & $35(2)$ \\
\hline Duodenal ulcer & $34(9)$ & $25(8)$ & $15(13)$ & $474(15)$ & $155(10)$ & $110(5)$ \\
\hline Gastric cancer/malignancy & $9(2)$ & $5(2)$ & 1 (1) & $24(1)$ & $12(1)$ & $45(2)$ \\
\hline Esophagitis & $59(15)$ & $44(15)$ & $12(10)$ & NA & NA & $295(13)$ \\
\hline Other diagnoses & $18(5)$ & $0(0)$ & $0(0)$ & $119(4)$ & $49(3)$ & $27(1)$ \\
\hline Total & 400 & 293 & 179 & 3187 & 1601 & 2253 \\
\hline
\end{tabular}

NA: not assessed

A severity questionnaire of the eight most frequently occurring and most severe symptoms of dyspepsia has recently been validated for research purposes [9].

Symptom pattern has a poor predictive value for the underlying cause of dyspepsia (see sub-chapter 1.4), and we have thus elected to group patients with upper abdominal symptoms as defined above, using the term "dyspepsia" in the indication matrix. This summary specifically refers to uncomplicated dyspeptic symptoms and the average-risk patient. Patients with weight loss, anemia, evidence of gastrointestinal bleeding, obstruction, dysphagia or odynophagia, immunodeficiency or other systemic illnesses are not considered to be typical patients in the context of the summary which follows. Furthermore, patients presenting with isolated heartburn or regurgitation are discussed in a separate article on GERD in this issue of the Journal [10] .

\section{Occurrence of Dyspepsia}

The prevalence of dyspeptic symptoms in the general population is estimated to be 14 to $41 \%[7,11-13]$, with geographical differences in the prevalence of dyspepsia, for example between Sweden (19\%) and England (41\%) [14]. Population surveys suggest that about $25 \%$ of patients with dyspepsia seek medical attention $[12,15]$. The prevalence of dyspepsia is characterised by an important turnover when measuring onset and disappearance rates [11]: Johnsen et al. examined the association between dyspeptic symptoms and endoscopic and histological diagnoses. With the exceptions of peptic ulcer disease and endoscopic duodenitis, they found no association of clinical value [16].

\section{Etiology of Dyspepsia}

Among random dyspeptic patients, endoscopy is considered normal in 25 to $76 \%[17-25]$. Table 1 shows the prevalence of endoscopic changes in dyspeptic patients (combined results of five European prospective studies including 7.853 patients).
Many gastroenterologists and pathologists have come to realise that endoscopic appearances frequently do not predict histological alterations. Gastric biopsy is therefore an essential part of routine endoscopic examination regardless of the macroscopic appearance of the mucosa [26].

Increasing age is related to higher frequency of organic disease in dyspeptic patients [17,20,21,27-30]. Cancer is rarely found in patients below 45 years of age. Table 2 it lustrates the aggregate results of three studies $[17,20,21]$.

Helicobacter status has a significant influence on the pres. alence of organic disease at endoscopy in patients with dyspepsia, Most gastric and duodenal ulcers, and most gastric cancers are thus associated with a positive Helicobacter status; erosive and non-erosive gastritis as well as duodenitis are significantly more frequent in Helicobacter-positive than in Helicobacter-negative patients. whereas the frequency of esophagitis does not seem to be different between the two groups. Table 3 shows the prevalence of organic disease in dyspeptic patients with respect to HP stafus (combined results [17-19], including a total of 1.964 patients).

\section{Predictive Value of Symptoms for Organic Diagnosis in Dyspepsia}

The classification of ulcer-like, reflux-like, dysmoulity. like, non-specific symptoms was first formally tested by Talley [23]. In a prospective evaluation of 820 outpatients referred for endoscopy, $31 \%$ of patients fitted into mors than one historical dyspepsia subgroup, and 27 had non. specific symptoms that could not be classified. Symptom alone were not found to be sensitive in differentiating pa. tients with organic disease from patients with non-organis symptoms. These findings were confirmed in other studies $[21,31-33]$. Dysmotility-like dyspepsia was found to re. sult more often in a negative endoscopy [2I]. There was no predictive value as regards the patients' predictions of their own diagnoses [32]. In a simulation stady of three dyspeptic symptom complexes performed with general practitioners, it was recently found that there is a consider- 
Table 2 Prevalence of endoscopic changes in dyspeptic patients, by age category

\begin{tabular}{|c|c|c|c|c|c|c|c|c|c|c|c|c|}
\hline & \multicolumn{2}{|c|}{ Heikkinen 1995} & \multirow[b]{2}{*}{$\geq 45$} & \multirow[b]{2}{*}{$\%$} & \multicolumn{2}{|c|}{ Mansi 1993} & \multirow[b]{2}{*}{$\geq 40$} & \multirow[b]{2}{*}{$\%$} & \multicolumn{2}{|c|}{ Vaira 1997} & \multirow[b]{2}{*}{$>45$} & \multirow[b]{2}{*}{$\%$} \\
\hline & $<45$ & $\%$ & & & $<40$ & $\%$ & & & $<45$ & $\%$ & & \\
\hline Normal & 66 & 73 & 188 & 61 & 152 & 37 & 478 & 26 & 613 & 29 & 553 & 21 \\
\hline Gastritis/erosions & 0 & 0 & 0 & 0 & 80 & 19 & 703 & 38 & 788 & 38 & 1183 & 44 \\
\hline Duodenitis & 1 & 1 & 8 & 3 & 75 & 18 & 253 & 14 & 290 & 14 & 354 & 13 \\
\hline Gastric ulcer & 1 & 1 & 16 & 5 & 11 & 3 & 24 & 1 & 45 & 2 & 129 & 5 \\
\hline Duodenal ulcer & 3 & 3 & 31 & 10 & 51 & 12 & 59 & 3 & 280 & 13 & 349 & 13 \\
\hline $\begin{array}{l}\text { Gastric cancer/ } \\
\text { malignancy }\end{array}$ & 0 & 0 & 9 & 3 & 0 & 0 & 45 & 2 & 2 & 0 & 34 & 1 \\
\hline Other diagnoses & 20 & 22 & 57 & 18 & 42 & 10 & 280 & 15 & 78 & 4 & 90 & 3 \\
\hline Total & 97 & 100 & 309 & 100 & 411 & 100 & 1842 & 100 & 2096 & 100 & 2692 & 100 \\
\hline
\end{tabular}

Table 3 Prevalence of organic disease in dyspeptic patients with respect to HP status [17-19]

\begin{tabular}{|c|c|c|c|c|c|c|}
\hline & Total HP pos & $\%$ pos & Total HP neg & $\%$ neg & Total & $\%$ \\
\hline Normal & 279 & 22 & 324 & 47 & 603 & 31 \\
\hline Gastritis/erosions & 522 & 41 & 251 & 36 & 773 & 39 \\
\hline Oesophagitis: & 27 & 2 & 29 & 4 & 56 & 3 \\
\hline Duodenitis & 179 & 14 & 64 & 9 & 243 & 12 \\
\hline Gastric ulcer & 58 & 5 & 18 & 3 & 76 & 4 \\
\hline Duodenal ulcer & 187 & 15 & 8 & 1 & 195 & 10 \\
\hline Gastric cancer/malignancy & 16 & 1 & 2 & 0 & 18 & 1 \\
\hline Total & 1268 & 100 & 696 & 100 & 1964 & 100 \\
\hline
\end{tabular}

able variation in the reliability with which different symptoms are reported [34], which may partially explain the inability of conventional history-taking to identify the cause of dyspepsia.

Appropriate preliminary screening of patients with acute dyspepsia can separate a group at low risk who will require investigations only if their symptoms do not resolve from a group at high risk requiring urgent outpatient consultations [35]. Numans et al. found that pain on an empty stomach, absence of pain after a meal, together with age, sex, information on former dyspeptic diseases, medication and smoking could predict peptic ulcer with an AUC (area under the curve) of 0.78 [36]. In the study of Muris et al. higher age, male sex, pain at night, relief by antacids or food, and previous history of peptic ulcer disease were identified as predictors of organic cause for abdominal symptoms [37].

\section{Helicobacter pylori in Dyspepsia}

Prevalence/Incidence of Helicobacter pylori

Helicobacter pylori is found in 10 to $52 \%$ of asymptomatic individuals $[8,38-42]$. The prevalence of HP increases with age but is not correlated with gender [39-41]. With the advent of improved living conditions, the incidence of HP infection has probably decreased over the generations $[43,44]$.
Relationship between Helicobacter pylori and Peptic Ulcer Disease (PUD)

Various investigators have documented H. pylori infection in 90 to $100 \%$ of patients with duodenal ulcers and 70 to $90 \%$ of patients with gastric ulcers [45-47]. In patients with duodenal ulcers, Helicobacter eradication results in long-lasting remission. At one year, ulcers had recurred in $2 \%$ of antibiotic-treated patients compared to $85 \%$ of untreated patients [48]. H. pylori treatment has also been shown to be effective in preventing recurrence of gastric ulcers. One study documented a 2-year recurrence rate of $13 \%$ in patients with gastric ulcers randomised to treatment with triple antibiotic therapy, compared to $74 \%$ of the group treated with ranitidine only [45].

Relationship between Helicobacter pylori and Non-Ulcer Dyspepsia (NUD)

In contrast to gastroduodenal ulcer disease, gastric malignancy and proven gastritis, there is still a lack of convincing evidence of a causal relationship between Helicobacter pylori and NUD $[7,49]$. Most studies thus did not report a significant difference in symptoms between Helicobacter-positive and Helicobacter-negative patients with non-ulcer dyspepsia [50-52]. A recent French consensus conference summarised the results of 15 studies which attempted to establish a causal link between HP infection and dyspepsia [53]: the level of evidence for such an asso- 
ciation is poor. A recent meta-analysis of HP prevalence rates in NUD and asymptomatic control patients indicates that prevalence is greater in patients with NUD than in the controls (difference $23 \%$ ) [54]. The studies analysed were, however, heterogeneous and the definition of dyspepsia was not standardised, making comparisons difficult.

Studies evaluating the impact of eradication treatment in NUD have not yielded convincing results. Almost all studies showed major methodological flaws, including small sample size, lack of long-term follow-up and use of ill-defined outcome measures. Some of these studies have shown improvement of symptoms after eradication [5559] while others failed to show any such improvement [50,60-62]. In 1998, four placebo-controlled randomised trials were reported in abstract form of which one showed improvement of symptoms after eradication treatment [63], whereas the three others did not $[64-66]$. In the positive English MRC trial [63], $21 \%$ of the patients that had received eradication treatment were asymptomatic after one year, compared to $7 \%$ who received placebo treatment. Although this is statistically significant, the therapeutic gain was only $14 \%$, and the $7 \%$ placebo rate found in this study is surprisingly low. If we compare these results with the Australian study [66], we see that the placebo response rates after one year were similar, $21.8 \%$ versus $24.1 \%$, after eradication treatment.

It has to be remembered that the Maastricht recommendations supporting eradication treatment in non-ulcer dyspepsia [7] contradict the NIH consensus [67] and the recommendations of the British Society of Gastroenterology [68].

A systematic review of various drug treatments in functional dyspepsia, summarising data for 3,978 patients from 52 trials, did not provide evidence of an effective treatment for NUD [69].

\section{Diagnosis of Helicobacter pylori Infection}

Diagnosis of Helicobacter pylori infection can be made by invasive tests, requiring endoscopy (histology, cultures, $\mathrm{PCR}$, rapid urease test) or non-invasive tests $\left({ }^{13} \mathrm{C}\right.$-urea breath-test, serology). These tests vary in sensitivity and specificity but most of them are highly accurate [70] (Table 4 ).

The gold-standard for diagnosis of HP infection is endoscopic biopsy of the antral mucosa with histological confirmation of the organism's presence [71]. The CLO-test is the most widely used and studied rapid urease test with maximum sensitivity 24 hours after biopsy [72]. Serology is recommended for non-endoscopic screening. Commercially available serological kits for HP infection show an overall sensitivity of $85 \%$ and a specificity of $79 \%$, with no test being found to be more accurate than any other [73]. The performance of practice-based serological kits may need to be improved before recommending their general use for screening. The urea breath-test is the best non-
Table 4 Sensitivity of diagnostic tests for Helicobacter pylori (Megraud (70) )

\begin{tabular}{lcc}
\hline & Sensitivity \% & Specificity \% \\
\hline Histology & 93.6 & 97.7 \\
Culture & 98.4 & 100 \\
PCR & 96.7 & 100 \\
Rapid urease test & 90.2 & 100 \\
${ }^{13}$ C-urea breath test & 100 & 100 \\
Serology & 98.4 & 88.4 \\
\hline
\end{tabular}

invasive test to determine eradication [74]. The major disadvantage of non-invasive tests compared to endoscopy is their lack of anatomical information about the presence of gastroduodenal ulceration.

\section{Efficacy of Eradication Treatment}

Eradication of Helicobacter pylori is the most clinicallyrelevant outcome of $\mathrm{H}$. pylori treatment. Eradication treatment should aim at an eradication rate of well over $80 \%$. It is now accepted that one should use a PPI-based triple therapy for seven days, using two antibiotics (clarithromycin, amoxicillin, tetracycline or metronidazole) [75.76]. A recent meta-analysis showed the superiority of combining two antibiotics, as opposed to one antibiotic alone. with acid-lowering therapy [77]. PPI (omeprazole) alone has been shown to reduce bacterial density in the antral mucosa, but does not eradicate $\mathrm{H}$. pylori [78]. Pre-treatment with omeprazole alone resulted in substantially lower eradication rates $(28 \%)[78]$.

Table 5 (consensus statement of the American College of Gastroenterology, 1996) gives a summary of the efficacy of different drug combinations and $\mathrm{H}$. pylori cure rates [76].

Within the context of a randomised trial, success rates for eradication therapy generally reflect efficacy. If good compliance can be achieved, the effectiveness of the various H. pylori eradication regimens was $84 \%$ in an ongoing community-based study [79]. There is now evidence that eradicating HP in patients who present with a bleeding ulcer reduces the risk of rebleeding [80-83].

The Maastricht consensus report [75], representing current European concepts in the management of HP infection. stated that eradication treatment is strongly recommended in the following situations: infected peptic ulcer patients including those in remission or receiving long-term anti-secretory therapy, patients with bleeding peptic ulcer. lowgrade MALT lymphoma, gastritis with severe macro- or microscopic abnormalities, and following resection of gastric cancer. MALT lymphomas often regress completely after eradication, rendering gastrectomy unnecessary [84$86]$. 
Table 5 Cure rates of various Helicobacter pylon eradication regimens (Soll [76])

\begin{tabular}{ll}
\hline Drug combination (duration) & HP cure rates $(95 \% \mathrm{Cl})$ \\
\hline MOC (1 wk) & $87-91$ \\
AOC (1 wk) & $86-91$ \\
MOA (1 wk) & $77-83$ \\
BMT (1 wk) & $86-90$ \\
BMT (2 wk) & $88-90$ \\
BMT + O (1 wk) & $94-98$ \\
BMA (1 wk) & $75-81$ \\
BMA (2 wk) & $80-86$ \\
\hline
\end{tabular}

Legends A amoxicillin, B bismuth, $\mathrm{C}$ clarithromycin, $\mathrm{M}$ metronidazole, $T$ tetracycline. O: omeprazole:

Side-effects, usually mild, affect $10 \%$ of patients receiving triple therapy including bismuth [87]. Omeprazole-based triple therapy was better tolerated than bismuth-based therapy in a randomised controlled trial [88].

\section{Recurrence after Eradication Treatment}

Ulcer recurrence is significantly less common among H. pylori-cured patients versus uncured patients $(6 \%$ ys. $67 \%$ for duodenal ulcer, $4 \%$ vs. $59 \%$ for gastric ulcer) [89]. The follow-up time in these studies ranged from six to 33 months. In a recently-published prospective longterm follow-up study [90] in non-NSAIDs users with endoscopically confirmed ulcer healing and eradicated H. pylori, no ulcer recurrence was detected over a period of up to 9,8 years.

Confirmation of the success of Helicobacter eradication is generally considered necessary in patients with persisting [80] or relapsing symptoms [87] after eradication therapy. Symptoms alone may not allow to distinguish between ulcer recurrence and reflux esophagitis as a substantial $(10 \%)$ proportion of duodenal ulcer patients developed reflux esophagitis after H. pylori eradication [91]. Endoscopy therefore seems indicated in these cases. The annual reinfection rate after successful eradication therapy is low $(1.2 \%)[92]$.

\section{Impact of Endoscopy on Patient Outcome}

There is only limited direct evidence of endoscopic impact on outcome in patients with dyspepsia; that is, studies comparing the outcome of patients with dyspeptic symptoms who either did or did not undergo diagnostic endoscopy. Three studies merit discussion here. The first study [93] randomised dyspeptic patients to empirical $\mathbf{H}_{2}$-blocker therapy or endoscopy/upper Gl series prior to prescription of $\mathrm{H}_{2}$-blockers. By the end of six months, $\mathrm{H}_{2}$-blocker use in both groups was similar (II vs. $8.7 \%$ ). Equal numbers of patients in each group were asymptomatic (42.5 vs. $39.5 \%$ ). The second study [94] compared initial upper GI radiography to antacids and reassurance. After six months of follow-up, there were no significant differences in symptoms, disability, satisfaction or quality of life scores between the two groups, The third study [95] compared prompt endoscopy with $\mathrm{H}_{2}$-blocker therapy, In contrast to the two other studies, this trial [95] showed better outcome (less work loss, less drug use) and lower costs in the group randomised to prompt endoscopy. Two-thirds of the patients initially randomised to empirical treatment were finally endoscoped at one year. In all three studies, Helicobacter pylori infection was not assessed.

An alternative approach to establishing the efficacy of endoscopy in patients with dyspepsia is to examine population trends. The first study [96] examined rates of peptic ulcer-related mortality, hospitalisation. surgery, physician visits, work loss and disability retirements in the US from 1977 to 1986. All these factors declined over time. The time-scale trends described were attributed to several factors, including the introduction of $\mathrm{H}_{2}$-blocker therapy, reduction in smoking and possible changes due to the increasing use of endoscopy. The second study [97] retrospectively reviewed the use of endoscopy compared to peptic ulcer mortality between 1979 and 1989. Although the utilisation of endoscopy rose from 21.7 to 25.6 procedures per thousand, the mortality rate for peptic ulcer disease increased by $4 \%$ in women while remaining stable in men. Death certification rates from peptic ulcer declined over the four decades in both sexes [98]. The main determinant of this is believed to be the introduction of $\mathrm{H}_{2}$-receptor antagonists in the late $1970 \mathrm{~s}$, but other factors, such as therapeutic endoscopy, may also have played a role. A population-based study [99] dealing with diagnosis, treatment and prognosis of gastric cancer showed that endoscopy is progressively becoming the only viable diagnostic tool. These changes in diagnostic strategy were, however, associated with less remarkable trends in treatment and stage at diagnosis, thus failing to demonstrate an important contribution by endoscopy to improving outcome of gastric cancer. In summary, population studies and studies comparing outcome before and after introduction of endoscopy have generally not shown conclusively that the introduction of endoscopy substantially affected patient outcome.

\section{Clinical Practice: Management Strategies in Dyspepsia}

When developing appropriateness criteria for gastrointestinal endoscopy, the still-unanswered question of how diagnosis and treatment of this condition should best be managed is crucial. Considerable confusion may exist in the literature as primary care physicians use the term "dyspepsia" in general to describe a complex of symptoms referable to the upper digestive tract, whereas specialists (gastroenterologists) often refer to this term once endoscopy is negative (i.e. non-ulcer dyspepsia). Increasing costs, efforts to contain costs, endoscopic workload and long waiting lists do not allow endoscopy to be offered to every dyspeptic patient although there is evidence that symptoms show a poor predictive value for endoscopic diagnoses [23, 
31], and that a "normal" result may substantially reduce work loss and medical care consumption [24].

From a conceptual standpoint, endoscopy can be restricted to certain patients either based on the response to empirical therapy or based on criteria such as age, HP status, intake of NSAIDs or warning symptoms. Both approaches will be discussed briefly.

\section{Decision to Endoscope Based on the Response to Empirical Therapy}

In 1985, the American College of Physicians issued a practice guideline for dyspepsia [100], which was also adopted some years later by the American Society for Gastrointestinal Endoscopy [101]. Although not based on a clinical trial, this consensus statement recommended empirical anti-secretory therapy in all patients with uncomplicated dyspepsia, reserving a diagnostic upper Gl endoscopy for those patients who did not respond to therapy or whose symptoms recurred on cessation of treatment. This recommendation was based on observations that a precise anatomical diagnosis did not impact on the choice of treatment for most of the diseases associated with dyspeptic symptoms at that time. Furthermore, it was hoped that empirical treatment would improve case selection for organic diagnoses at endoscopy. The role of empirical treatment as a decision tool for deciding on the use of endoscopy has been questioned. Bytzer [95] has shown that case selection of organic diagnoses is not reliably enhanced by empirical treatment as only $60 \%$ of ulcer patients could be identified with this strategy, In addition, empirical therapy proved to be more expensive due to higher work loss and drug consumption. Furthermore, empirical treatment postpones rather than eliminates the need for endoscopy [102] as dyspeptic symptoms recur and two-thirds of patients randomised to empirical treatment were thus finally endoscoped after one year [95]. Empirical treatment may also lead to an erroneous diagnosis of functional dyspepsia in patients with endoscopic lesions who have not experienced symptom relief but have undergone complete healing of the lesion (e.g. ulcer) because the relationship between symptoms and ulcer healing is not conclusive [102]. Empirical therapy therefore proved to be a weak selection criterion for endoscopy.

\section{Decision to Endoscope Based on Specific Patient-Related Characteristics}

Sobala [19] assessed a policy of screening dyspeptic patients before endoscopy using a strategy based on Helicobacter status and use of non-steroidal anti-inflammatory drugs. He used three criteria to identify patients expected to show a low yield from diagnostic endoscopy: 1) age $<45$ years; 2) negative $H$. pylori test, and 3) no history of NSAIDs use. The sereening criteria were applied retrospectively in 842 patients with known histological $\mathrm{H}$. pylori status, and prospectively to 293 patients referred for diagnostic endoscopy. Overall, this screening strategy would have reduced endoscopy workload by $23.3 \%$ and would have had a sensitivity rate for detection of peptic ulcer of $97.4 \%$. No peptic ulcer or malignant disease was missed in the patients studied prospectively, but six out of 192 peptic ulcers in the histology (i.e., retrospective) group would have been missed. In another study [103], 52 subjects aged 45 or less were screened by HP serology. All 27 who were sero-negative had no ulcer disease while seven out of 25 sero-positive patients had ulcer disease. Screening would have avoided $35 \%$ of endoscopies in these patients while missing $13 \%$ of patients with endoscopic findings (esophagitis and gastritis). In a further study [18], 183 dyspeptic patients aged $<45$ were screened by a history-taking of sinister symptoms and regular use of NSAIDs, together with serological testing for $\mathrm{H}$. pylori. Endoscopy was performed in 113 patients, of whom 90 were sero-positive, 14 had sinister symptoms, and nine had used NSAIDs regularly. The remaining 70 patients who were $\mathrm{H}$. pylori sero-negative had no sinister symptoms and had not taken NSAIDs, did not undergo endoscopy but received symptomatic treatment. Of these patients, only three were re-referred after screening for endoscopy. Thus, $67(37 \%)$ endoscopies were avoided. When the non-endoscoped screening-negative patients were compared with the cohort of endoscoped screening-negative patients, there was no difference between the groups in terms of symptom severity. Medication use was, however, significantly less in those patients who did not undergo endoscopy [18]. This study indicates that a screening based on $\mathrm{H}$. pylori serology, a history of sinister symptoms (e. g. weight loss, hemorrhage) or a history of NSAIDs use was beneficial in dyspeptic patients. Thirty-seven percent of endoscopies were avoided, and drug usage was reduced without disadvantaging those patients not endoscoped.

The above-mentioned studies all took place in patients referred for endoscopy. Two randomized studies, published as abstracts in 1998, prospectively compared a "test and treat" strategy (i.e., H. pylori-positive patients with dyspepsia received eradication therapy without endoscopy) with prompt endoscopy in primary care. In the first study [104] which included 500 patients, no difference between the two groups was found with respect to rate of symptom-free days, severity of symptoms or number of sick leave days after one year follow-up. However, the prompt endoscopy group resulted in higher patient satisfaction whereas the "test and treat" group was, not surprisingly, associated with a significant $(63 \%)$ reduction in endoscopic work load. $\mathrm{Pa}$ tients with alarm symptoms were excluded from the study. and patients taking NSAIDs were automatically endoscoped. The cost-effectiveness of a "test and treat" strategy, compared to prompt endoscopy, was confirmed in another randomized controlled trial [105]. However, none of these studies directly compared a "test and treat" strategy with a "test and scope" strategy (i.e., H.pylori-positive patients with dyspepsia are routinely endoscoped) in primary care. This might yield different results, in as much that the cost advantage of a "test and treat" strategy may be less evident 
and the problem of overtreatment with eradication therapy (see below) would be avoided.

The question of whether patients testing positive for Helicobacter pylori should be endoscoped ("test and scope") or treated ("test and treat") continues to be hotly debated, with indirect evidence coming from several decision analyses. The first decision analysis [106] in HP-positive patients with dyspepsia concluded that initial anti-H. pylori therapy is the most cost-effective management strategy. Results were not substantially affected by varying the degree of H. pylori eradication, by the side-effects of antibiotics, or the range of symptoms in curing $\mathrm{H}$. pylori infection. Endoscopy-related costs would need to be reduced by $96 \%$ before the two strategies become equally cost-effective. Another decision analysis [107] concluded that eradication treatment is less costly than $\mathrm{H}_{2}$-blocker therapy in patients under 45 years of age with dyspepsia. The model in this study used endoscopy to identify appropriate patients to receive eradication treatment (patients with ulcer disease). When the initial cost of identifying appropriate patients for eradication treatment is added to the analysis, the cost savings of eradication treatment take almost eight years to accrue. Similar results were obtained in a third decision analysis [108]. A further decision analysis came to a different result. Direct medical charges in the first year after the onset of dyspepsia were compared between three strategies: prompt endoscopy, empirical therapy $\left(\mathrm{H}_{2}\right.$-blockers) or testing for H. pylori [109]. Medical charges were 2162 US dollars for prompt endoscopy and 2122 US dollars for empirical therapy. Initial non-invasive testing for $\mathrm{H}$. pylori cost less than prompt endoscopy if $\mathrm{H}$. pylori-positive patients with dyspepsia received antimicrobial therapy without endoscopy (that is, "test and treat" strategy) but would have cost more if patients with $\mathrm{H}$. pylori were routinely endoscoped ("test and scope" strategy). The authors concluded that the choice of the optimal management strategy was a "toss-up". Only very modest savings may result from practice guidelines that recommend empirical anti-HP therapy in the management of patients with dyspepsia.

At the present time, randomized studies directly comparing the "test and scope" and the "test and treat" strategies in primary care are needed to evaluate outcome and patient preferences. The value of each strategy will depend on the prevalence of $\mathrm{H}$. pylori (low prevalence allowing more savings than high prevalence in the "test and scope" strategy). the still unproved impact of HP eradication therapy on outcome in documented non-ulcer dyspepsia, patient and doctor preferences, and the cost of endoscopy (very variable according to the country). As the cost of upper GI endoscopy differs greatly between the United States ( $>1000$ US dollars) and Europe, cost-effectiveness of upper GI endoscopy must be judged differently. Thus, endoscopy may be cost competitive if its cost is $200-500$ US dollars [110], which is the case in most European countries. The following table briefly summarises the pros and cons of the "test and scope" (Table 6) and the "test and treat" (Table 7) strategies:
Table 6 "Test and scope" strategy

\begin{tabular}{lc}
\hline Pros & Cons \\
\hline $\begin{array}{l}\text { Establishes clear diagnoses } \\
\text { and allows biopsies }\end{array}$ & $\begin{array}{c}\text { Cost of endoscopy (variable } \\
\text { according to country) }\end{array}$ \\
- Allows exclusion of neoplasia & $\begin{array}{c}\text { Potential complications of } \\
\text { upper Gl endoscopy (rare) }\end{array}$ \\
- Reduces anxiety & - Inconvenience of endoscopy \\
(patients' and physicians') & (unpleasantness, pain, time, \\
& etc.) \\
- Avoids over-treatment of & \\
patients who would not need & \\
eradication therapy & \\
(e.g esophagitis) & \\
- Cost-effective if cost of \\
endoscopy under 500 US \\
dollars $[110]$
\end{tabular}

Table 7 "Test and treat" strategy

\begin{tabular}{lc}
\hline Pros & Cons \\
\hline - Lowers the general HP & Over-treatment of patients \\
prevalence and thus the & who do not need eradication \\
future risk of gastric & therapy (e.g esophagitis/ \\
carcinoma and HP-related & reflux disease, non-ulcer \\
diseases & dyspepsia) \\
- Dramatic reduction of & - Potential deterioration of \\
endoscopic work-load with & reflux symptoms \\
consequent cost savings & \\
- Allows management in & Missing of significant \\
primary care & endoscopic diagnoses \\
& (e.g. gastric ulcer, neoplasia, \\
& Barrett's esophagus) \\
- Development of resistance & to antibiotics \\
& - Side-effects of antibiotics \\
& - Insufficient sensitivity and \\
& specificity of rapid HP \\
& serology kits
\end{tabular}

In conclusion, the question of whether "test and scope" or "test and treat" should be the preferred management strategy remains open. Taking into account the uncertain efficacy of eradication treatment in non-ulcer dyspepsia with the huge risk of "overtreatment" in a test and treat strategy, the lower cost of endoscopy in Europe, current state of knowledge and all the pros and cons stated above, a "test and scope" strategy seems, at the present time, preferable. However, uncertainty will make this question one of the most prominent to be debated.

\section{Surveillance Endoscopy in Patients with Known Ulcer Disease}

It has become standard practice to follow gastric, but not duodenal ulcers endoscopically up to healing, because of concerns that gastric ulcers may represent early gastric malignancy. Diagnosis of gastric cancer in apparently benign 
gastric ulcers has been reported in 1 to $6 \%$ of patients with gastric ulcer [111-113]. Bytzer et al. evaluated the benefits of routine endoscopic follow-up of gastric ulcer to detect malignancy. They found that each curable gastric cancer was found at the expense of approximately 250 followup endoscopies [114]. To our knowledge, there has been no randomized controlled trial or prospective study comparing outcome for patients with and without endoscopic followup of gastric ulcer to healing. Two retrospective studies reviewed the clinical course in patients diagnosed with gastric ulcer. The first study [115] reviewed 148 gastric ulcers followed up by serial endoscopy over a 5 -year period. One hundred and seven patients were followed to healing and 41 cases did not heal. The average number of endoscopies per case was 2.7. Of 67 gastric cancers diagnosed during the same time period, 62 were suspected of being malignant by their macroscopic appearance and only one cancer was missed after biopsy and/or brush cytology. The authors estimate that favoring a policy of single endoscopy without follow-up when all signs indicate a benign ulcer would result in significant cost savings, as compared to the practice of routine follow-up endoscopy. Another study [111] looked at the impact of gastric ulcer surveillance to detect gastric carcinoma after surgery. Patients with macroscopically and histologically benign gastric ulcer were asked to return after four weeks of therapy. Of 142 patients with an initial diagnosis of benign gastric ulcer, $1.8 \%$ had malignancy documented on repeat examination. Follow-up examinations did not, however, result in significant differences in 5-year survival rates. A large population-based longterm cohort study [116] in hospitalised patients with gastric or duodenal ulcers found that the risk of gastric cancer was almost twice the expected rate in patients with gastric ulcers, whereas the risk was less in patients with duodenal ulcers. The authors conclude that gastric ulcer disease and gastric cancer have etiological factors in common.

\section{Dyspepsia in Patients Taking NSAIDs}

\section{Prevalence of NSAID-Induced Gastro-Duodenal Disease}

The use of NSAIDs in the general population is extremely frequent. In a population-based study in the USA, age- and gender-adjusted annual prevalence rates for aspirin and non-aspirin NSAIDs use in the elderly were $60 \%$ and $26 \%$ respectively [117]. Fifteen percent of these patients presented with dyspepsia, 13\% with heartburn. NSAIDs are the second most common cause of peptic ulcer and are now believed to be responsible for the majority of those ulcers not associated with H. pylori infection [118]. In a meta-analysis of 16 studies from 1975 to 1990 , examining the association between NSAID use and adverse gastrointestinal events, NSAID users were calculated to be at a threefold greater risk of development of serious adverse events (GI bleeding, surgery or death) than non-users [119]. The risk appeared to be greatest in the first few months of treatment, age $>65$, in the presence of concomitant steroid use and where there was a previous history of G1 events [119]. In a case-control study [118], the relative risk for development of peptic ulcer disease among current NSAID users was 4.1 , with the greatest risk in the first month of use. NSAID use is associated with a higher rate of dyspepsia [117]. However, symptoms are not strong predictors of the presence of endoscopic damage [120]. More recent NSAID types have been claimed to have less damaging effects on the gastro-duodenal mucosa, primarily by inhibiting more selectively cyclooxygenase- 2 , and thus increasing tolerability $[121,122]$. Nabumetone thus seems to have significantly lower ulcerogenic potential than naproxen $[123,124]$, but probably also less clinical efficacy [124] NSAID use is also associated with non-specific ulceration of the small intestinal mucosa $(8.4 \%$ of the patients) that can lead to life-threatening complications [125].

\section{NSAID-Induced Ulcer Disease and Helicobacter pylori}

In NSAIDs users, there is no difference in the frequency of dyspeptic symptoms between patients with and without HP infection, suggesting that NSAIDs do not increase susceptibility to Helicobacter infection [126, 127]. A randomized study recently showed that eradication of Helicobacter pylori before starting NSAIDs therapy reduces the occurrence of NSAID-induced peptic ulcers [128]. In this study. H. pylori seems to have a pathogenic role in NSAID-induced ulcer disease. In contrast, three randomized trials published as abstracts in 1998 failed to show a beneficial impact of HP eradication on NSAID-induced ulcers. Thus eradication treatment did not accelerate the healing of already established ulcers [129] nor prevent the development of ulcers in long-term NSAID users. [130]. A third trial even showed that eradication treatment was associated with reduced ulcer healing [131]. In conclusion, eradication of HP in chronic NSAID users is probably not justified.

\section{Prophylaxis of NSAID-Induced Ulcers}

A large meta-analysis on the prevention of NSAID-induced mucosal injury in 4,325 patients [132] concluded that misoprostol, but not $\mathrm{H}_{2}$-blockers, reduced the risk of gastric ulcers. It was also found that both misoprostol and $\mathrm{H}_{2}$. blockers prevented duodenal ulcer in long-term NSAIDsusers. These findings were confirmed in other randomised controlled trials [133-135]. Misoprostol was also shown to significantly reduce serious NSAID-induced upper gastrointestinal complications such as perforation, gastric outlet obstruction and bleeding. These results were obtained in large, well-conducted, randomised trials in 8,843 patients with chronic rheumatoid arthritis [134]. However, misoprostol is often associated with side-effects such as diarrhea and abdominal cramps [136]. The prophylactic effect of omeprazole in NSAIDs users was recently assessed in a placebo-controlled, randomised study [136]. During a 3 month study period, $4.7 \%$ of omeprazole-treated patients developed duodenal or gastric ulcers, compared with $16.7 \%$ of placebo-treated patients. In addition, the development of dyspeptic symptoms was also significantly reduced with omeprazol, compared to placebo. 
In a double-blind randomized study published in 1998 [137], omeprazole healed and prevented ulcers more effectively than did ranitidine in NSAIDs users. Another double-blind randomized trial comparing omeprazole $20 \mathrm{mg}$, $40 \mathrm{mg}$ or misoprostol $800 \mathrm{mg}$ daily found that the overall bealing rates of ulcers and symptoms were similar for the three treatment regimens. However, omeprazole was better tolerated and associated with a lower rate of relapse during maintenance treatment than misoprostol [138].

\section{Impact of Endoscopy in NSAIDs Users}

There are to our knowledge no studies comparing outcome of patients with uncomplicated NSAID-induced peptic disease with and without endoscopy.

\section{Stress Ulcer}

Although endoscopic studies have demonstrated gross mucosal injury within hours of a stressful event in nearly $100 \%$ of patients examined, most stress ulcers heal when normal gastric defence mechanisms are restored. In a randomised, controlled trial [139], $80 \%$ of patients requiring aortic surgery developed stress ulcers post-operatively. A rigorously-conducted meta-analysis published recently [140], and including 63 randomised trials in 7.218 patients, addressed ulcer prophylaxis in critically-ill adult patients. Sucralfate was associated with a lower morbidity rate compared with antacids and a trend towards lower mortality when compared with $\mathrm{H}_{2}$-receptor antagonists. However, none of the three treatments studied (sucralfate, $\mathrm{H}_{2}$-receptor antagonists. NSAIDs) revealed a significant effect on mortality rate. Stress-ulcer bleeding is rare $(1-1.5 \%)$ $[141,142]$. Sucralfate significantly decreased overt bleeding in comparison with both placebo and NSAIDs. For clinically-important bleeding, $\mathrm{H}_{2}$-receptor antagonists remained superior to placebo.

The role of PPI in stress ulcer prophylaxis has been studied in a recent randomized trial. Sixty-seven high-risk patients were randomized to receive either ranitidine $150 \mathrm{mg}$ or omeprazole $40 \mathrm{mg}$ per day [143]. Eleven patients in the ranitidine and two patients in the omeprazole group developed clinically important bleeding $(p<0.05)$. Despite its potent acid inhibition, nosocomial pneumonia was seen in one patient only under omeprazole, compared to 5 patients receiving ranitidine. Further studies are needed to determine the role of PPI in stress ulcer prophylaxis [144].

Only a small proportion of patients presenting with complications such as gastrointestinal hemorrhage or perforation, require medical and/or surgical intervention [145]. The role of endoscopy in bleeding stress ulcers is discussed in a separate publication (upper gastrointestinal bleeding and other alarm symptoms) [146].

\section{Complicated Peptic Ulcer Disease}

Hemorrhage as a complication of ulcer disease has been dealt with in a separate publication [146]. The epidemiology of peptic ulcer perforation has evolved over the past 50 years; incidence has decreased, except in women over 65 years of age, and there has been an increase in mean age at time of perforation and a decrease of the male: female ratio [147]. The short-term mortality of peptic ulcer disease has fallen from 1952 to 1990 [148]. Uncertainty remains about the role of Helicobacter pylori in the pathogenesis of ulcer perforation since $50 \%$ of patients with perforation seem to be HP-negative [147]. The single most important risk factor associated with both ulcer perforation and ulcer bleeding is the increasing use of NSAIDs [147]. The localisation of perforation has also changed over time, with perforation now being more frequently encountered in the pyloric and prepyloric area than in the duodenum [149].

\section{Gastric Cancer}

Prevalence, Incidence and Risk Factors of Gastric Cancer

The prevalence of gastric cancer in dyspeptic patients in Europe is in the order of $1-2 \%$. In three recent prospective studies [17,20,21], two gastric cancers were found in 2,598 dyspeptic patients under 40 years of age $(0.8 \%)$, vs. 88 cases in 4,843 patients over 40 to 45 years $(1.8 \%)$, showing a striking higher-age predominance with gastric cancer being very rare in young dyspeptic patients.

Fifty years ago, stomach cancer was the leading cause of death from cancer in males in the USA. Since then, mortality and incidence have decreased virtually everywhere. There is a band of high- and above-average incidence from Central Italy to the Swiss border, continuing through $\mathrm{Ba}$ varia up to the Danish border, while the south of Italy, Great Britain and most of France are either average or below-average $[150,151]$. These trends are believed to be due to changes in food preparation and storage, and differences in consumption of fruit and vegetables. Classical risk conditions for gastric cancer are the following [152]: chronic atrophic gastritis and intestinal metaplasia, pernicious anemia, partial gastrectomy for benign disease, Helicobacter pylori infection, Ménétrier's Disease, gastric adenomatous polyps. Genetic and environmental factors include a family history of gastric cancer, low consumption of fruit and vegetables, consumption of salted, smoked foods, cigarette smoking, low social and economic status, and blood type A.

Helicobacter pylori was declared a Class 1 carcinogen in June 1994 (World Health Organisation). Available evidence on the relationship between Helicobacter pylori and gastric cancer was assessed in a 1996 consensus statement [153]. $\mathrm{HP}$ is the major cause of multifocal atrophic gastritis and is also believed to lead to the development of intestinal metaplasia [98], while chronic gastritis is clearly not associated with any increased risk of cancer [153]. The Eurogast 
Study Group [41], a prospective epidemiological study in over 3,000 subjects of 14 populations in Europe, USA and Japan, found a six-fold increased risk of gastric cancer in populations with $100 \% \mathrm{HP}$ infection compared with populations without infection. The hypothesis that HP infection is a risk factor for gastric cancer is further endorsed by three large case-controlled studies [154-156]. Most persons infected with HP will, however, never develop a gastric carcinoma and other factors that increase the risk of carcinoma among persons infected with HP therefore need to be identified [156]. Early-life infection by Helicobacter pylori increases the risk of developing both gastric cancer and gastric ulcers [157].

Helicobacter pylori infection is invariably associated with the presence of lymphoid follicles which are precursors of MALT lymphomas [153]: There is evidence that the successful cure of Helicobacter pylori infection results in the regression, and perhaps even the cure, of MALT lymphoma in $50-75 \%$ of patients [84].

\section{Symptoms of Gastric Cancer}

Although gastric cancer is a matter of concern for clinicians evaluating patients with dyspepsia, most patients with gastric cancer do not develop symptoms or signs until the disease is no longer curable. Superficial and surgically curable gastric carcinoma typically produce no symptoms [152]. In a prospective series of 720 patients with gastric carcinoma, only $8 \%$ were eligible for curative resection [158]. In a large review performed by the American College of Surgeons [152], weight loss $(62 \%)$ and abdominal pain $(52 \%)$ were the most frequent symptoms at the time of initial diagnosis. About $10 \%$ of all gastric cancer patients present with hematemesis or melena, and patients presenting with bleeding rarely have early cancers [159].

\section{Histological Issues in Gastric Cancer}

Differences in diagnostic criteria for gastric carcinoma between Japanese and Western pathologists may contribute to the relatively high incidence and good prognosis of gastric cancer in Japan. Thus, in Japan, gastric carcinoma is diagnosed on nuclear and structural criteria even when invasion is absent according to the Western viewpoint [160]. In a prospective, multi-center study, it was found that gastric cancer was associated with $36 \%$ of moderate and with $80 \%$ of severe gastric epithelial dysplasia; the follow-up of patients with dysplasia considerably enhances the chances of diagnosing gastric cancer in its early stages [161]. In these patients, a repeat endoscopy every three months is recommended in presence of moderate dysplasia with immediate control endoscopy and multiple biopsies in the presence of severe dysplasia.

\section{Impact of Endoscopy on Detection Rate}

There have been important changes in the diagnostic strategy for gastric cancer, endoscopy being now the most frequently-used diagnostic tool [99]. The proportion of resections for cure increased from 38 to $50 \%$, as did the proportion of cases confined to the gastric wall $(6-12 \%)$. The investigation of dyspeptic patients over 40 years of age after their first consultation with the general practitioner could increase the proportion of early gastric cancers detected to $26 \%$ and the proportion of operable cases to $63 \%$ [162]. The most obvious trends in the management of gastric cancer come from the reduction of operative mortality rate. Endoscopic surveillance in post-gastrectomy patients, aiming at detecting early gastric-stump cancer, does not seem to reduce mortality [163], and the risk of developing gastric cancer in these patients does not seem to be enhanced as compared to the general population [164]. Endoscopic ultrasound has been shown to better assess $\mathrm{T}$ and $\mathrm{N}$ categories pre-operatively than computed tomography or interoperative surgical assessment [165-167].

\section{Panel Results}

Considering the above review of relevant literature, the panel evaluated 192 specific theoretical patient scenarios related to the use of gastrointestinal endoscopy in patients with dyspepsia.

\section{Definition of Terms}

All terms and definitions were reviewed and approved by the panelists before proceeding to ratings of clinical indications; they are listed in Table 8.

\section{Clinical Variables}

The clinical variables used to describe the list of indications related to dyspepsia are shown in Table 9. The main variable used to structure the list of indications for dyspepsia was the parameter of previous investigations, resulting in four main sub-categories.

\section{General Panel Results}

Dyspepsia was assessed by 192 clinical scenarios within 4 sub-categories: no previous investigation done (48 items). previous or upper Gl (UGI) series upper GI endoscopy (UGE) normal (48 items), UGE or UGI series done and showing duodenal or prepyloric ulcer, duodenitis or erosive gastritis (48 items), and UGE or UGI series showing gastric ulcer (48 items). Of the 192 scenarios, the panel rated $113(59 \%)$ as inappropriate, $31(16 \%)$ as uncertain and 48 $(25 \%)$ as appropriate. The rate of overall agreement between panelists was high ( $72 \%$ of the scenarios). Although a distinction was initially made between first/second and recurrent episodes, the panelists did not wish to maintain this distinction, arguing that their clinical judgment would 
Table 8 Definition of terms

\section{Dyspepsia}

is defined as pain or discomfort in the upper abdomen, including nausea, vomiting, early satiety, epigastric fullness, but not heartburn or dysphagia.(Isolated heartburn or regurgitation are dealt with in the article on reflux disease [10].

\section{Uncomplicated dyspepsia}

Dyspepsia without alarm symptoms. (Hematemesis, melena, esophageal dysphagia, unexplained weight loss, iron-deficiency anemia are dealt with in the article on alarm symptoms [146].

\section{Episode of dyspepsia}

Minimum duration to be considered as one episode: 4 weeks. Time interval for the definition of the onset of a new episode: 1 month free of symptoms without treatment.

Eradication treatment for Helicobacter pylori infection Treatment regimen composed of two antibiotics and an PP/ $/ \mathrm{H}_{2}$ blocker with an eradication rate supposed to exceed $90 \%$.

Helicobacter test

According to the situation, either a non-endoscopic test

(serology, $C_{13}$ breath-test), or an endoscopic test (urease test. histology, culture).

Empirical acid-lowering treatment

In order to serve as a decisional tool for the panel, the minimum duration of treatment is $\geq 1$ week of continuous intake. The type of treatment is either standard doses of an PPI (e.g. omeprazole $20 \mathrm{mg} / \mathrm{d}$, lansoprazole $30 \mathrm{mg} / \mathrm{d}$, or pantoprazole $40 \mathrm{mg} / \mathrm{d}$ ) or $\mathrm{H}_{2}$-blockers (e.g. ranitidine $300 \mathrm{mg} / \mathrm{d}$ ) or continuous high-dose antacid treatment (e. g. $4 \times 5 \mathrm{ml} / \mathrm{d}$ aluminium hydroxide, sucralfate $2 \times 2 \mathrm{~g} / \mathrm{d}$ etc).

NSAIDs intake

Continuous intake of NSAIDs for $\geq 3$ days, or intermittent intake of NSAIDs at onset of symptoms at least every 2 days for at least 1 week

Previous investigations

A previous investigation by either an UGI endoscopy or UGI series. performed within 2 years of the present episode of dyspepsia. be similar in each case. Appropriateness is defined in a separate publication in this issue of the Journal [1].

\section{Specific Clinical Panel Results}

Description of Appropriateness

The main results related to appropriateness are worded as an overall statement (Table 10) encompassing several clinical scenarios (clustering). In some cases, the same scenario may apply to more than one statement. One hundred and sixty-seven of the 192 indications ( $94 \%$ ) could be characterized by the eight overall statements given below. Detailed appropriateness and necessity criteria encompassing all 192 indications are available in a computerized form accessible via Internet (http://www.epage.ch).

In HP-positive patients with persisting symptoms and not having received eradication treatment, we assessed whether panelists would favor a "test-and-scope" strategy (i.e., endoscope dyspeptic patients testing positive for $\mathrm{H}$. pylori) or a "test-and-treat" strategy (i.e., treat dyspeptic patients empirically if testing positive). Sixteen scenarios pertain to this situation. In patients $>45$ years of age, the "test-andscope" strategy was favored unless previous investigations showed duodenal or prepyloric ulcer or duodenitis. In the presence of a previous history of gastric ulcer, the "testand-scope" strategy was always preferred. The "test-andtreat strategy" was preferred if previous investigations had shown duodenal or prepyloric ulcer or duodenitis, or in patients $<45$ years of age in whom previous UGE or UGI series were normal,

Table 9 Clinical variables used in individuais presenting with dyspepsia (192 indications)

\begin{tabular}{|c|c|c|}
\hline Variables & Number of categories & Categories \\
\hline Age & 2 & $\begin{array}{l}-\geq 45 \text { years old } \\
-<45 \text { years old }\end{array}$ \\
\hline NSAIDS & 2 & $\begin{array}{l}\text { - no } \\
\text { - yes }\end{array}$ \\
\hline Helicobacter pylori & 3 & $\begin{array}{l}\text { - no HP test } \\
\text { - HP test negative } \\
\text { - HP test positive }\end{array}$ \\
\hline Previous investigations of similar symptoms & 4 & $\begin{array}{l}\text { - no previous investigation or previous investigation } \\
\text { with results unknown } \\
\text { - UGl endoscopy or UGI series with normal results } \\
\text { - UGl endoscopy or UGI series showing duodenal } \\
\text { ulcer, prepyloric ulcer, duodenitis or erosive gas- } \\
\text { tritis } \\
\text { - UGl endoscopy or UGI series showing gastric ulcer }\end{array}$ \\
\hline $\begin{array}{l}\text { Empirical acid-lowering treatment } \\
\text { (in HP-negative patients) or HP eradication } \\
\text { treatment (in HP-positive patients) }\end{array}$ & 2 & $\begin{array}{l}\text { - no treatment or inadequate treatment } \\
\text { - adequate treatment given }\end{array}$ \\
\hline $\begin{array}{l}\text { Response to empirical acid-lowering or } \mathrm{HP} \\
\text { eradication treatment, respectively }\end{array}$ & 2 & $\begin{array}{l}\text { - symptoms not resolved } \\
\text { - symptoms resolved }\end{array}$ \\
\hline
\end{tabular}


Table 10 Description of appropriateness of indications for upper gastrointestinal endoscopy in individuals with dyspepsia

\section{Clinical Situation}

In individuals with uncomplicated dyspeptic symptoms that resolved with or without treatment, indication for gastrointestina! endoscopy is generally inappropriate with the exception of some scenarios related to patients $\geq 45$ years old with previous gastric ulcer (uncertain)

In individuals with persistent dyspepsia, and with a previous history of gastric ulcer, indication for gastrointestinal endoscopy is appropriate

In individuals aged 45 and over with persistent dyspepsia, and without any previous investigations or with unknown results of previous investigations, indication for gastrointestinal endoscopy is appropriate

In individuals aged 45 and over with persistent dyspepsia, and normal results of previous investigations of similar symptoms, indication for gastrointestinal endoscopy is generally uncertain unless symptoms persist after HP eradication has been given in a HP-positive patient (appropriate)

In individuals aged 45 and over with persistent dyspepsia, and previous investigations showing duodenal ulcer, prepyloric uker or duodenitis, indication for gastrointestinal endoscopy is

generally uncertain

unless empiric acid lowering treatment has been given and HP test is negative (appropriate)

unless symptoms persist after HP eradication has been given in a HP-positive patient (appropriate)

In individuals aged less than 45 with persistent dyspepsia, and without any previous investigations or with unknown results of previous investigations, indication for gastrointestinal endoscopy is generally uncertain

unless HP test is unknown and no empirical acid-lowering treatment has been given (inappropriate)

unless symptoms persist after HP eradication has been given in a HP-positive patient (appropriate)

In individuals aged less than 45 with persistent dyspepsia, and normal results of previous investigations of similar symptoms, indication for gastrointestinal endoscopy is inappropriate unless symptoms persist after HP eradication has been given in a HP-positive patient (uncertain)

In individuais aged less than 45 with persistent dyspepsia, and previous investigations showing duodenal ulcer, prepyloric ulcer or duodenitis, indication for gastrointestinal endoscopy is inappropriate

unless empirical acid lowering treatment has been given and HP status is negative or unknown (uncertain)

unless symptoms persist after HP eradication has been given in a HP-positive patient (appropriate)

\section{Description of Necessity}

Twelve out of 192 scenarios $(6.3 \%)$ were judged necessary. All necessary indications (Table 11) in uncomplicated dyspepsia pertained to patients $>45$ years of age. Necessity is defined in a joint publication in this issue of the Journal [1].

\section{Conclusions}

The current literature underlines the frequent occurrence of dyspepsia in clinical practice and the wide variations in diagnosis and treatment. The advent of Helicobacter pylori
Table 11 Description of necessity of indications for upper gastrointestinal endoscopy in individuals with dyspepsia

\section{Clinical situation}

In individuals $>45$ years of age testing positive for HP, with persisting symptoms despite eradication treatment, indication for gastrointestinal endoscopy is necessary

In individuals > 45 years of age, never investigated, HP-negative and no NSAIDs intake, with persisting symptoms despite acdlowering treatment, indication for gastrointestinal endoscopy is necessary

In individuals $>45$ years of age with a previous history of gastric ulcer, no HP testing or HP test negative, with persisting symptoms despite acid-lowering treatment, indicatıon for gastrointestinal endoscopy is necessary

as well as the need for cost containment in almost all developed countries have had a profound impact on diagnostic and therapeutic strategies in dyspepsia which are currently hotly debated and widely assessed. The literature suggests that UGE should be used in patients with a reasonably high probability of a clinically relevant diagnosis such as ulcer disease or cancer.

One third of EPAGE criteria related to dyspepsia. EPAGE criteria judged performance of UGE often inappropriate $(59 \%)$ in uncomplicated dyspepsia. Very few situations $(6 \%)$ were judged necessary, Six clinical and circumstantial parameters permitted detailed assessment of all possible scenarios: patient age, NSAIDs intake, Helicobacter status, results of previous UGE or UGI series, whether or not empirical antisecretory treatment was given and the clinical response to this treatment. Although highly detailed and specific, $94 \%$ of the scenarios could be encompassed in simple, descriptive statements applicable to clinical practice. However, the full potential and utility of these criteria will become apparent on the computerised version accessible via Internet (http://www.epage.ch) that will permit easy application of all scenarios even in the most complex situations.

\section{Acknowledgement}

The authors gratefully acknowledge the selfless commitment and invaluable contribution of the expert panel members, who made this project possible: Marcello Anti (IT), Peter Bytzer (DK), Mark Cottrill (UK), Michael Fried (CH), Roar Johnsen (NO), Gerd Kanzler (DE), François Lacaine (FR), Cornelis Lamers (NL), Roger J. Leicester (UK), Mattijs E. Numans (NL), Javier P. Piqueras (SP), Jean-François Rey (FR), Giacomo Sturniolo (IT), Robert P. Walt (UK).

This work was supported by the EU BIOMED II Programme (BMH4-CT96-1202), the Swiss National Science Foundation (32.40522.94) and the Swiss Federal Office of Education and Science (95.0306-2). 


\section{References}

Vader JP, Burnand B, Froehlich F, et al. The European Panel on Appropriateness of Gastrointestinal Endoscopy (EPAGE): Project and Methods. Endoscopy 1999; 31:572-578

${ }^{2}$ Vader JP, Froehlich F, Dubois RW, et al. The European Panel on Appropriateness of Gastrointestinal Ensocopy (EPAGE): Conclusions and WWW site. Endoscopy 1999; 31: 687-694

${ }^{3}$ Morrissey JF, Reichelderfer M. Gastrointestinal endoscopy (2). N Engl I Med 1991; 325: 1214-1222

4 Colin-Jones DG. Management of dyspepsia: report of a working party. Lancet 1988; 1: 576-579

${ }^{5}$ Talley NJ. Phillips SF. Non-ulcer dyspepsia: potential causes and pathophysiology. Ann Intern Med 1988; 108: 865-879

${ }^{\circ}$ Barbara L, Camilleri M, Corinaldesi R, et al, Definition and investigation of dyspepsia. Consensus of an international ad hoc working party. Dig Dis Sci 1989; 34: 1272-1276

7 Malfertheiner P, McColl K. Baldi F, et al. Update on Helicobacter pylori research. Dyspepsia. Eur J Gastroenterol Hepatol 1997: 9: 624-625

${ }^{8}$ Agreus L, Engstrand L, Svardsudd K, et al. Helicobacter pylori seropositivity among Swedish adults with and without abdominal symptoms. A population-based epidemiologic study. Scan J Gastroenterol 1995; 30: 752-757

${ }^{9}$ Veldhuyzen van Zanten SJ, Tytgat KM, Pollak PT, et al. Can severity of symptoms be used as an outcome measure in trials of non-ulcer dyspepsia and Helicobacter pylori associated gastritis? J Clin Epidemiol 1993: 46: 273-279

${ }^{10}$ Bochud M. Gonvers JJ, Vader JP, et al. Appropriateness of gastroscopy; Gastroesophageal reflux disease. Endoscopy 1999; 31: $596-603$

11 Talley NJ, Weaver AL, Zinsmeister AR, et al. Onset and disappearance of gastrointestinal symptoms and functional gastrointestinal disorders. Am J Epidemiol 1992; 136: 165-177

12 Talley NJ, Zinsmeister AR, Schleck CD, et al. Dyspepsia and dyspepsia subgroups: a population-based study. Gastroenterology 1992; 102: 1259-1268

13 Jones RH, Lydeard SE, Hobbs FD, et al. Dyspepsia in England and Scotland. Gut 1990; 3: 401-405

${ }^{14}$ Knill-Jones RP. Geographical differences in the prevalence of dyspepsia. Scan J Gastroenterol 1991; 26; 17-24

15 Jones R. Dyspeptic symptoms in the community. Gut 1989; 30: $893-898$

${ }^{16}$ Johnsen R, Bernersen B. Straume B, et al. Prevalences of endoscopic and histological findings in subjects with and without dyspepsia. BMJ 1991; 302: 749-752

17 Vaira D, Stanghellini V, Menegatti M, et al. Prospective screening of dyspeptic patients by Helicobacter pylori serology: a safe policy? The Italian Helicobacter pylori Study Group. Endoscopy 1997: 29: 595-601

${ }^{18}$ Patel P, Mendall MA, Khulusi S, et al. Salivary antibodies to Helicobacter pylori: screening dyspeptic patients before endoscopy. Lancet 1994; 344: $511-512$

${ }^{19}$ Sobala GM, Crabtree JE, Pentith JA, et al. Screening dyspepsia by serology to Helicobacter pylori. Lancet 1991; 338: 94-96

${ }^{20}$ Heikkinen M, Pikkarainen P, Takala J, et al. Etiology of dyspepsia: four hundred unselected consecutive patients in general practice. Scan J Gastroenterol 1995; 30: 519-523

${ }^{21}$ Mansi C, Mela GS, Savarino V, et al. Open access endoscopy: a large-scale analysis of its use in dyspeptic patients. J Clin Gastroenterol 1993; 16: 149-153

${ }^{22}$ Bernersen B, Johnsen R, Bostad L, et al. Is Helicobacter pylori the cause of dyspepsia? BMJ 1992; 304: 1276-1279
${ }^{23}$ Talley NJ, Weaver AL, Tesmer DL, et al. Lack of discriminant value of dyspepsia subgroups in patients referred for upper endoscopy. Gastroenterology 1993; 105; 1378-1386

${ }^{24}$ Hansen JM, Bytzer P, Bondesen S, et al, Efficacy and outcome of an open access endoscopy service. Dan Med Bull 1991; 38 : $288-290$

${ }^{25}$ Fraser AG, Ali MR, McCullough S, et al. Diagnostic tests for Helicobacter pylori - can they help select patients for endoscopy? New Zealand Medical Journal 1996; 109: 95-98

${ }^{26}$ Carpenter HA, Talley NJ. Gastroscopy is incomplete without biopsy: clinical relevance of distinguishing gastropathy from gastritis. Gastroenterology 1995; 108: 917-924

${ }^{27}$ Richter JE. Dyspepsia: organic causes and differential characteristics from functional dyspepsia. (Review) Scand J Gastroenterol Suppl 1991; 182: 11-16

${ }^{28}$ Williams B, Luckas M, Ellingham $\mathrm{JH}$, et al. Do young patients with dyspepsia need investigation? Lancet $1988 ; 2$ : 1349 1351

${ }^{29}$ Bytzer P, Schaffaiitzky de Muckadell OB. Prediction of major pathologic conditions in dyspeptic patients referred for endoscopy. A prospective validation study of a scoring system. Scan J Gastroenterol 1992; 27: 987-992

${ }^{30}$ Kalra L, Price WR, Jones BJ, Hamlyn AN. Open access fibresigmoidoscopy: a comparative audit of efficacy, $\mathrm{Br}$ Med J Clin Res Ed 1994; 1998; 6629; 1095-1096

${ }^{31}$ Mansi C, Mela GS, Pasini D, et al. Patterns of dyspepsia in patients with no clinical evidence of organic diseases. Dig Dis Sci 1990; 35: 1452-1458

${ }^{32}$ Bytzer P, Hansen JM, Havelund T, et al. Predicting endoscopic diagnosis in the dyspeptic patient: the value of clinical judgement. Eur J Gastroenterol Hepatol 1996; 8: 359-363

${ }^{33}$ Adang RP, Ambergen AW, Talmon JL, et al. The discriminative value of patient characteristics and dyspeptic symptoms for upper gastrointestinal endoscopic findings: A study on the clinical presentation of 1147 patients. Digestion 1996; 57: $118-134$

${ }^{34}$ Heading RC. Wager E, Tooley PJ, Reliability of symptom assessment in dyspepsia. Eur J Gastroenterol Hepatol 1997; 9: $779-781$

${ }^{35}$ Davenport PM, Morgan AG, Darnborough A, de Dombal FT. Can preliminary screening of dyspeptic patients allow more effective use of investigational techniques? Brit Med J Clin Res Ed $1994 ; 1985 ; 6463: 217-220$

${ }^{36}$ Numans ME, Van der Graaf Y, de Wit NJ, et al. How much ulcer is ulcer-like? Diagnostic determinants of peptic ulcer in open access gastroscopy. Family Practice 1994; II: 382-388

${ }^{37}$ Muris JW, Starmans R, Pop P. Discriminant value of symptoms in patients with dyspepsia. J Fam Pract 1994; 38: 139-143

${ }^{38}$ Dooley CP, Cohen H, Fitzgibbons PL, et al. Prevalence of $\mathrm{He}$ licobacter pylori infection and histologic gastritis in asymptomatic persons. N Engl J Med 1989; 321: 1562-1566

${ }^{39}$ Graham DY, Malaty HM, Evans DG, et al. Epidemiology of Helicobacter pylori in an asymptomatic population in the United States. Effect of age, race, and socioeconomic status. Gastroenterology 1991; 100: 1495-1501

${ }^{40}$ Gasbarrini G, Pretolani S, Bonvicini F, et al. A population based study of Helicobacter pylori infection in a European country: the San Marino study. Relations with gastrointestinal diseases. Gut 1995; 36: 838-844

41 Anonymous. An international association between helicobacter pylori infection and gastric cancer. The Eurogast study group. Lancet 1993; 341: 1359-1362 
${ }^{42}$ Goodman KJ, Correa P. The transmission of Helicobacter pylori. A critial review of the evidence. Int J Epidemiol 1995; 24: $875-887$

${ }^{43}$ Kuipers EJ, Pena AS, Van Kamp G, et al. Seroconversion for Helicobacter pylori infection. Lancet $1993 ; 342: 328-331$

${ }^{44}$ Megraud F. Epidemiology of Helicobacter pylori infection: where are we in 1995? Eur J Gastroenterol Hepatol 1995: 7: 292-295

${ }^{45}$ Graham DY, Lew GM, Klein PD, et al. Effect of treatment of Helicobacter pylori infection on the long-term recurrence of gastric or duodenal ulcer. A randomized, controlled study. Ann Intern Med 1992; 116: 705-708

${ }^{46}$ Peterson WL. Helicobacter pylori and peptic ulcer disease (see comments). (Review) (97 refs). N Engl I Med 1991; 324 : 1043-1048

${ }^{47}$ Rauws EA. Role of Helicobacter pylori in duodenal ulcer. Drugs 1992; 44:921-927

${ }^{48}$ Hentschel E, Brandstatter G, Dragosics B, et al. Effect of ranitidine and amoxicillin plus metronidazole on the eradication of Helicobacter pylori and the recurrence of duodenal ulcer. $\mathrm{N}$ Engl J Med 1993; 328: 308-312

${ }^{49}$ Veldhuyzen van Zanten SJ, Sherman PM. Helicobacter pylori infection as a cause of gastritis, duodenal ulcer, gastric cancer and nonulcer dyspepsia: a systematic overview. Can Med Assoc J 1994; 150: 177-185

${ }^{50}$ Elta GH, Scheiman JM, Barnett JL, et al. Long-term follow-up of Helicobacter pylori treatment in non-ulcer dyspepsia patients. Am J Gastroenterol 1995; 90: 1089-1093

si Greenberg RE, Bank S. The prevalence of Helicobacter pylori in nonulcer dyspepsia, Importance of stratification according to age. Arch Intern Med 1990; 150: 2053-2055

${ }^{52}$ Holtmann G, Goebell H, Holtmann M. Talley NJ. Dyspepsia in healthy blood donors. Pattern of symptoms and association with Helicobacter pylori. Dig Dis Sci 1994; 39: 1090- 1098

${ }^{53}$ Bouche $\mathrm{O}$. Should Helicobacter pylori be eradicated in a patient with chronic gastritis? (Review) (127 refs) (French). Gastroenterol Clin Biol 1996; 20: SI43-S153

${ }^{54}$ Armstrong D. Helicobacter pylori infection and dyspepsia. Scand J Gastroenterol Suppl 1996; 215; 38-47

${ }^{55}$ McCarthy C. Patchett S, Collins RM, et al. Long-term prospective study of Helicobacter pylori in nonulcer dyspepsia. Dig Dis Sci 1995; 40: 114-119

${ }^{56}$ Gilvarry J, Buckley MJ, Beattie S, et al. Eradication of Helicobacter pylori affects symptoms in non-ulcer dyspepsia. Scan J Gastroenterol 1997: 32: 535-540

${ }^{57}$ Sheu BS, Lin CY, Lin XZ, et al. Long-term outcome of triple therapy in Helicobacter pylori-related nonulcer dyspepsia: a prospective controlled assessment. Am J Gastroenterol 1996; 91: $441-447$

${ }^{58}$ Lazzaroni M, Bargiggia S, Sangaletti $\mathrm{O}$, et al. Eradication of Helicobacter pylori and long-term outcome of functional dyspepsia. A clinical endoscopic study. Dig Dis Sci 1996; 41 : $1589-1594$

${ }^{59} \mathrm{O}$ 'Morain C, Gilvarry J. Eradication of Helicobacter pylori in patients with non-ulcer dyspepsia. (Review) $(40 \mathrm{rfs})$. Scand J Gastroenterol Suppl 1993; 196: 30-33

${ }^{60}$ Veldhuyzen van Zanten SJ, Malatjalian D. The effect of eradication of Helicobacter pylori on symptoms of non-ulcer dyspepsia (NUD): a randomized, double blind, placebo-controlled trial (abstract). Gastroenterology 1995; 108: A250

${ }^{61}$ Greenberg PD. Prospective, double-blind treatment of Helicobacter pylori in patients with non-ulcer dyspepsia. (Abstract). Gastroenterology 1996; 110: A123
${ }^{62}$ Schubert TT, Schubert AB. Ma CK. Symptoms, gastritis, and Helicobacter pylori in patients referred for endoscopy. Gastrointest Endose 1992; 38: 357-360

${ }^{63} \mathrm{McC}$ oll KEL, U.K. MRC trial of $\mathrm{H}$. pylori eradication therapy for non-ulcer dyspepsia. (Abstract), Gastroenterology 1998: 114: A222-A222

${ }^{64}$ Koelz HR. Treatment of Helicobacter pylori does not improve symptoms of functional dyspepsia. (Abstract). Gastroenterology 1998; 114: A182-A182

${ }^{65}$ Bretagne JF. The course of symptoms after eradication of Helicobacter pylori: a one-year follow-up of a cohort of 258 patients with duodenal ulcer or nonulcer dyspepsia. (Abstract). Gastroenterology 1998; 114: A81-A81

${ }^{66}$ Talley NJ. Long-term follow-up of patients with non-ulcer dyspepsia after Helicobacter pylori eradication. A randomized double-blind placebo-controlled trial. (Abstract), Gastroenterology 1998: 114: A305-A305

${ }^{67}$ Anonymous. Nih consensus conference. Helicobacter pylori in peptic ulcer disease. Nih consensus development panel on Helicobacter pylori in peptic ulcer disease. J Am Med Ass 1994. 272: 65-69

${ }^{68}$ Dyspepsia Management Guidelines. Brit Society of Gastroenterology, http://www.bsg.org.uk/clinical/data/dmg.htm: 1996

${ }^{69}$ Wilcox CM. Schwartz DA. Endoscopic characterization of idiopathic esophageal ulceration associated with human immunodeficiency virus infection. J Clin Gastroenterol 1993; 16: $251-256$

${ }^{70}$ Megraud F. Advantages and disadvantages of current diagnostic tests for the detection of Helicobacter pylori. Scand J Gastroenterol Suppl 1996; 215; 57-62

7 Ateshkadi A, Lam NP, Johnson CA. Helicobacter pylori and peptic ulcer disease. Clin Pharmacy 1993; 12:34-48

$7^{2}$ Laine L, Chun D, Stein C, et al. The influence of size or number of biopsies on rapid urease test results: a prospective evaluation. Gastrointest Endose 1996; 43: 49-53

${ }^{73}$ Loy CT, Irwig LM, Katelaris PH. Talley NJ. Do commercial serological kits for Helicobacter pylori infection differ in accuracy? A meta-analysis. Am J Gastroenterol 1996: 91: 11381144

${ }^{74}$ Megraud F. The most important diagnostic modalities for Helicobacter pylori, now and in the future. (Review) (4 refs). Eur J Gastroenterol Hepatol 1997; 1: S13-S15

${ }^{75}$ Malfertheiner P, Megraud F, O'Morain C. et al. Current european concepts in the management of Helicobacter pylori infection - the Maastricht consensus report. The European Helicobacter pylori study group. Eur J Gastroenterol Hepatol 1997; 9: $1-2$

${ }^{76}$ Soll AH. Consensus conference. Medical treatment of peptic ulcer disease. Practice guidelines. Practice parameters committee of the American College of Gastroenterology. J Am Med Ass 1996; 275: 622-629

77 Holtmann G, Layer P, Goebell H. Proton-pump inhibitors or h2-receptor antagonists for Helicobacter pylori eradication-a meta-analysis (letter). Lancet 1996:347: 763

${ }^{78}$ Labenz J, Gyenes E. Ruhl GH, Borsch G. Omeprazole plus amoxicillin: efficacy of various treatment regimens to eradicate Helicobacter pylori. Am J Gastroenterol 1993; 88: 491495

${ }^{79}$ Fennerty MB, Lieberman D, Magaret N, et al. Effectiveness of $\mathrm{H}$. pylori treatment regimens in clinical practice: a communitybased outcomes study. (Abstract). Gastroenterology 1997; 112 $\mathrm{A} 14-\mathrm{A} 14$ 
${ }^{80}$ Lee J, O'Morain C. Consensus or confusion: a review of existing national guidelines on Helicobacter pylori-related disease. Eur J Gastroenterol Hepatol 1997; 9: 527-53।

${ }^{81}$ Rokkas T, Karameris A, Mavrogeorgis A, et al. Eradication of Helicobacter pylori reduces the possibility of rebleeding in peptic ulcer disease. Gastrointest Endosc 1995; 41: 1-4

${ }^{82}$ Graham DY, Hepps KS, Ramirez FC, et al. Treatment of Helicobacter pylori reduces the rate of rebleeding in peptic ulcer disease. Scan J Gastroenterol 1993; 28: 939-942

${ }^{83}$ Jaspersen D, Koerner T. Schorr W, et al. Helicobacter pylori eradication reduces the rate of rebleeding in ulcer hemorrhage Gastrointest Endosc 1995; 41: 5-7

${ }^{84}$ Bayerdorffer E, Neubauer A, Rudolph B, et al. Regression of primary gastric lymphoma of mucosa-associated lymphoid tissue type after cure of Helicobacter pylori infection. MALT Lymphoma Study Group. Lancet 1995; 345: 1591-1594

${ }^{85}$ Wotherspoon AC, Doglioni C, Diss TC, et al. Regression of primary low-grade-B-cell gastric lymphoma of mucosa-associated lymphoid tissue type after eradication of Helicobacter pylori. Lancet 1993; 342: 575-577

${ }^{86}$ Sackmann M. Morgner A. Rudolph B, et al. Regression of gastric MALT lymphoma after eradication of Helicobacter pylori is predicted by endosonographic staging. Gastroenterology 1997: 113: 1087-1090

${ }^{87}$ Veldhuyzen von ZS, Sherman PM, Hunt RH. Helicobacter pylori: new developments and treatments. CMAJ 1997; 156: 1565-1574

${ }^{88}$ Lerang F, Moum B, Ragnhildstveit E, et al. A comparison between omeprazole-based triple therapy and bismuth-based triple therapy for the treatment of Helicobacter pylori infection: a prospective randomized 1-yr follow-up study. Am J Gastroenterol 1997; 92: 653-658

${ }^{89}$ Hopkins RJ, Girardi LS, Turney EA, et al, Relationship between Helicobacter pylori eradication and reduced duodenal and gastric ulcer recurrence: a review, Gastroenterology 1996: 110: 1244-1252

${ }^{90}$ Vanderhulst RM, Rauws EJ, Koycu B, et al. Prevention of ulcer recurrence after eradication of Helicobacter pylori - A prospective long-term follow-up study. Gastroenterology 1997 113: $1082-1086$

${ }^{91}$ Labenz J, Blum AL, Bayerdorffer E, et al. Curing Helicobacter pylori infection in patients with duodenal ulcer may provoke reflux esophagitis. Gastroenterology 1997; 112: 1442-1447

${ }^{92}$ Forbes GM, Glaser ME, Cullen DJ, et al. Duodenal ulcer treated with Helicobacter pylori eradication: seven-year follow-up. Lancet $1994 ; 343: 258-260$

${ }^{93}$ Goulston KJ, Dent OF, Logan J, et al. Use of H2-receptor antagonists in patients with dyspepsia and heartburn: a cost comparison. Med J Aust 1991: 155: 20-26

${ }^{94}$ Goodson JD, Lehmann JW, Richter JM, et al. Is upper gastrointestinal radiography necessary in the initial management of uncomplicated dyspepsia? A randomized controlled trial comparing empiric antacid therapy plus patient reassurance with traditional care, J Gen Intern Med 1989; 4: 367-374

${ }^{95}$ Bytzer P, Hansen JM, Schaffalitzky de Muckadell OB. Empirical H2-blocker therapy or prompt endoscopy in management of dyspepsia. Lancet 1994; 343: $811-816$

${ }^{96}$ Bloom BS. Cross-national changes in the effects of peptic ulcer disease. Ann Intern Med 1991; I I4: 558-562

${ }^{97}$ Westbrook J1. Rushworth RL. The epidemiology of peptic uicer mortality 1953-1989: a birth cohort analysis. Intern J Epidemiol 1993: 22: 1085-1092
${ }^{98}$ La Vecchia C. Lucchini F, Negri E, et al. The impact of therapeutic improvements in reducing peptic ulcer mortality in Europe. Intern J Epidemiol 1993; 22: 96-106

${ }^{99}$ Msika S, Tazi MA, Benhamiche AM, et al, Population-based study of diagnosis, treatment and prognosis of gastric cancer. Brit J Surg 1997; 84: 1474-1478

${ }^{100} \mathrm{Kahn}$ K. Endoscopy in the evaluation of dyspepsia. Health and Public Policy Committee, American College of Physicians. Ann Intern med 1985; 102:266-269

${ }^{101}$ American Society for Gastrointestinal Endoscopy. The role of endoscopy in the management of the patient with peptic ulcer disease. Guidelines for clinical application. Gastrointest Endose 1988; $34: 4 S-25 S$

${ }^{102}$ Bytzer P. Diagnosing dyspepsia: any controversies left? Gastroenterology 1996; 110; 302-306

${ }^{103}$ Tham TC. Application of serological screening for Helicobacter pylori in reducing endoscopy workload. Gastroenterology 1993; 104: A26

${ }^{104}$ Lassen AT. H. Pylori "test and treat" or prompt endoscopy for dyspeptic patients in primary care. A randomized controlled trial of two management strategies: one year follow-up. (Abstract), Gastroenterology 1998; 114: A196-A196

105 Jones RH. A Helicobacter test and treat strategy: costs and outcomes in a randomized controlled trial in primary care. (Abstract). Gastroenterology 1998; 114: A20-A20

${ }^{106}$ Ofman JJ, Etchason J, Fullerton S, et al. Management strategies for Helicobacter pylori-seropositive patients with dyspepsia - clinical and economic consequences. Ann Intern Med 1997; 126: 280-291

${ }^{167}$ Briggs AH, Sculpher MJ, Logan RP, et al. Cost effectiveness of screening for and eradication of Helicobacter pylori in management of dyspeptic patients under 45 years of age. $\mathrm{Br}$ Med J 1996; 312 : 1321-1325

${ }^{108}$ Fullerton E. Empiric antibiotic therapy versus early endoscopy in dyspeptic patients with positive serologic test for Helicobacter pylori: a decision analysis. (Abstract). Gastroenterology 1995; I08: A15

${ }^{100}$ Silverstein FE, Graham DY, Senior JR, et al. Misoprostol reduces serious gastrointestinal complications in patients with rheumatoid arthritis receiving nonsteroidal anti-inflammatory drugs. A randomized, double-blind, placebo-controlled trial. Ann Intern Med 1995; 123: 241-249

${ }^{110}$ Fendrick AM, Chernew ME. Hirth RA, Bloom BS. Immediate endoscopy or initial Helicobacter pylori serological testing for suspected peptic ulcer disease: estimating cost-effectiveness using decision analysis. Yale Journal of Biology \& Medicine 1996; 69: 187-195

${ }^{11}$ Eckardt VF, Giessler W, Kanzler G, Bernhard G. Does endoscopic follow-up improve the outcome of patients with benign gastric ulcers and gastric cancer? Cancer 1992; 69: 301-305

${ }^{112}$ Farinati F, Cardin F, Di Mario F, et al. Early and advanced gastric cancer during follow-up of apparently benign gastric ulcer: significance of the presence of epithelial dysplasia. J Surg Oncol 1987; $36: 263-267$

${ }^{113}$ Tragardh B, Haglund U. Endoscopic diagnosis of gastric ulcer. Evaluation of the benefits of endoscopic follow-up observation for malignancy. Acta Chir Scand 1985; 15:37-41

${ }^{114}$ Bytzer P. Endoscopic follow-up study of gastric ulcer to detect malignancy: is it worthwhile? Scandinavian Journal of Gastroenterology 1991; 26: 1193-1199

${ }^{115}$ Pruitt RE, Truss CD. Endoscopy, gastric ulcer, and gastric cancer. Follow-up endoscopy for all gastric ulcers? Dig Dis Sci $1993 ; 38: 284-288$ 
${ }^{116}$ Hansson LE, Nyren O, Hsing AW, et al. The risk of stomach cancer in patients with gastric or duodenal ulcer disease. $\mathrm{N}$ Engl J Med 1996; 335: 242-249

117 Talley NJ, Evans JM, Fleming KC, et al. Nonsteroidal antiinflammatory drugs and dyspepsia in the elderly. Dig Dis Sci 1995: 40: $1345-1350$

${ }^{118}$ Graham DY. Treatment of peptic ulcers caused by Helicobacter pylori (editorial; comment). N Engl J Med 1993; 328: 349 350

${ }^{119}$ Gabriel SE, Jaakkimainen L, Bombardier C. Risk for serious gastrointestinal complications related to use of nonsteroidal anti-inflammatory drugs. A meta-analysis. Ann Intern Med 1991: 115: 787-796

${ }^{120}$ Larkai EN, Smith JL, Lidsky MD, Graham DY, Gastroduodenal mucosa and dyspeptic symptoms in arthritic patients during chronic nonsteroidal anti-inflammatory drug use. Am J Gastroenterol 1987: 82: 1153-1158

${ }^{121}$ Battistini B, Botting R, Bakhle YS. COX-1 and COX-2: toward the development of more selective NSAIDs. Drug News and Perspectives (Barcelona) 1994; 7:501-512

122 Distel M. Mueller C, Bluhmki E, Fries J. Safety of meloxicam: a global analysis of clinical trials. Brit J Rheumatol 1996; 35 : 68-77

${ }^{123}$ Roth SH, Bennett R, Caldron P, et al. A longterm endoscopic evaluation of patients with arthritis treated with nabumetone vs naproxen. J Rheumatol 1994; $21: 1118-1123$

${ }^{124}$ Porro GB, Montrone F, Petrillo M, et al. Gastroduodenal tolerability of nabumetone versus naproxen in the treatment of rheumatic patients. Am J Gastroenterol 1995; 90: 1485-1488

${ }^{125}$ Allison MC, Howatson AG, Torrance CJ, et al. Gastrointestinal damage associated with the use of nonsteroidal antiinflammatory drugs (see comments). N Engl J Med 1992; 327: 749-754

${ }^{126}$ Graham DY, Lidsky MD, Cox AM, et al. Long-term nonsteroidal antinflammatory drug use and Helicobacter pylori infection. Gastroenterology 1991; 100: 653-657

${ }^{127}$ Loeb DS, Talley NJ, Ahlquist DA, et al Long-term nonsteroidal anti-inflammatory drug use and gastroduodenal injury: the role of Helicobacter pylori. Gastroenterology 1992; 102: $1899-1905$

${ }^{128}$ Chan FK, Sung JJ, Chung SC, et al. Randomized trial of eradication of Helicobacter pylori before non-steroidal anti-inflammatory drug therapy to prevent peptic uicers. Lancet 1997; 350: $975-979$

${ }^{129}$ Lai KC. Eradication of Helicobacter pylori did not accelerate the healing of gastric and duodenal ulcers/erosions in patients on long-term continuous nonsteroidal anti-inflammatory drugs. (Abstract). Gastroenterology 1998; 114: A192

${ }^{130}$ Lai KC. Can eradication of Helicobacter Pylori prevent future development of peptic ulcers in patients receiving long-term continuous nonsteroidal anti-inflammatory drugs. (Abstract). Gastroenterology 1998: 114: A192

${ }^{131}$ Hawkey CJ. Tullassay Z. Failure of Helicobacter Pylori eradication to influence site-specific relapse in high risk NSAID users: results of a large six month double blind randomized controlled clínical trial. (Abstract), Gastroenterology 1998; 114: A145

${ }^{132}$ Koch M, Dezi A. Ferrario F, Capurso L. Prevention of nonsteroidal anti-inflammatory drug-induced gastrointestinal mucosal injury - a meta-analysis of randomized controlled clincal trials. (Abstract). Arch Intern Med 1996; 156: 2321 - 2332

133 Taha AS, Hudson N. Hawkey CJ, et al. Famotidine for the prevention of gastric and duodenal ulcers caused by nonsteroidal antiinflammatory drugs. N Engl J Med 1996; 334: 1435-1439
${ }^{134}$ Agrawal NM. Van Kerckhove HE, Erhardt LJ, Geis GS. Misoprostol coadministered with diclofenac for prevention of gstroduodenal ulcers. a one-year study. Dig Dis Sci 1995; 40: $|125-| 13 \mid$

${ }^{135}$ Hudson N, Taha AS, Russell RI, et al Famotidine for healing and maintenance in nonsteroidal anti-inflammatory drug-associated gastroduodenal ulceration (see comments). Gastroenterology 1997: 112: $1817-1822$

${ }^{136}$ Ekstrom P, Carling L, Wetterhus S, et al. Prevention of peptic ulcer and dyspeptic symptoms with omeprazole in patients receiving continuous non-steroidal anti-inflammatory drug therapy. A Nordic multicentre study. Scan J Gastroenterol 1996; 31: $753-758$

${ }^{137}$ Yeomans ND, Tulassay Z, Juhasz L, et al. A Comparison of Omeprazole with Ranitidine for Ulcers Associated with Nonsteroidal Antiinflammatory Drugs. N Engl I Med 1998; 338: $719-726$

${ }^{138}$ Hawkey CJ, Karrasch JA, Szczepanski L, et al. Omeprazole Compared with Misoprostol for Ulcers Associated with Nonsteroidal Antiinflammatory Drugs. N Engl J Med 1998: 338: $727-734$

${ }^{139}$ Martin LF. Stress ulcers are common after aortic surgery, Endoscopy evaluation of prophylactic therapy. Am Surg 1994; 60: $169-174$

${ }^{140}$ Cook DJ, Reeve BK, Guyatt GH, et al. Stress ulcer prophylaxis in critically ill patients. Resolving discordant meta-analyses. J Am Med Ass 1996: 275: 308-314

${ }^{141}$ Zandstra DF. Stoutenbeek CP. The virtual absence of stress-ulceration related bleeding in ICU patients receiving prolonged mechanical ventilation without any prophylaxis. A prospective cohort study (see comments). Intens Care Med 1994; 20:335340

${ }^{142}$ Cook DJ, Fuller HD, Guyatt GH, et al. Risk factors for gastrointestinal bleeding in critically ill patients. Canadian Critical Care Trials Group. N Engl J Med 1994: 330: 377-381

${ }^{143}$ Levy MJ, Seelig CB, Robinson NJ, Ranney JE. Comparison of omeprazole and ranitidine for stress ulcer prophylaxis. Dig Dis Sci 1997; 42: 1255-1259

${ }^{144}$ Schepp W, Schusdziarra V. Classen M. (Stress ulcer prophylaxis 1995. Balancing between gastrointestinal bleeding and nosocomial pneumonia.) Dtsch Med Wochenstr 1995; 120: $573-579$

${ }^{145}$ Marrone GC, Silen W. Pathogenesis, diagnosis and traetment of acute gastric mucosal lesions. Clin Gastroenterol 1984; 13 : $635-650$

${ }^{146}$ De Bosset V, Gonvers JJ. Froehlich F, et al. Appropriateness of gastroscopy: Bleeding and dysphagia. Endoscopy 1999; 31 : $615-622$

${ }^{147}$ Hudson N. Excess long-term mortality in patients with ulcer complications. Lancet 1997: 349: $968-969$

${ }^{148}$ Svanes C, Lie RT, Lie SA, et al. Survival after peptic ulcer perforation: a time trend analysis. J Clin Epidemiol 1996; 49: $1363-1371$

${ }^{149}$ Svanes C. Salvesen H, Stangeland L, et al. Perforated peptic ulcer over 56 years. Time trends in patients and disease characteristics. Gut 1993: 3: 1666-1671

${ }^{150}$ International Agency for Research on Cancer. Atlas of cancer mortality in the European Economic Community. In: Smans M, Muir CS, Boyle P (eds). Lyon, France: IARC, 1992

${ }^{151}$ International Agency for Research on Cancer. Atlas of cancer mortality in Central Europe. In: Zatonski W, Smans M. Tyczynski J, et al. (eds). Lyon, France: IARC, 1996

${ }^{\text {IS2 }}$ Fuchs CS, Mayer RJ. Gastric carcinoma. N Engl J Med 1995 ; $333: 32-41$ 
${ }^{153}$ Gasbarrini G, Genta RM, Anti M, et al. Update on Helicobacter pylori research. Malignancies. Eur J Gastroenterol Hepatol 1997: 9: 621-623

154 Forman D, Newell DG, Fullerton F, et al. Association between infection with Helicobacter pylori and risk of gastric cancer: evidence from a prospective investigation. Brit Med J 1991; 302: $1302-1305$

155 Parsonnet J, Friedman GD, Vandersteen DP, et al. Helicobacter pylori infection and the risk of gastric carcinoma. $N$ Engl $J$ Med 1991; $325 ; 1127-1131$

${ }^{156}$ Nomura A, Stemmermann GN, Chyou PH, et al. Helicobacter pylori infection and gastric carcinoma among Japanese Americans in Hawaii. N Engl J Med 1991; 325: 1132-1136

${ }^{157}$ Blaser MJ, Chyou PH, Nomura A. Age at establishment of Helicobacter pylori infection and gastric carcinoma, gastric ulcer, and duodenal ulcer risk. Cancer Res 1995; 55: 562-565

${ }^{158}$ Matley PJ, Dent DM, Madden MV, et al. Gastric carcinoma in young adults. Ann Surg 1988: 208: 593-596

${ }^{159}$ Moreno-Otero R, Rodriguez S, Carbo J, et al. Acute upper gastrointestinal bleeding as primary symptom of gastric carcinoma. J Surg Oncol 1987; 36; 130-133

${ }^{100}$ Schlemper RJ, Itabashi M. Kato Y, et al. Differences in diagnostic criteria for gastric carcinoma between Japanese and Western pathologists. Lancet 1997; 349: 1725-1729

161 Farinati F, Rugge M. Di Mario F, et al. Early and advanced gastric cancer in the follow-up of moderate and severe gastric dysplasia patients. a prospective study. i.g.g.e.d-interdisciplinary group on gastric epithelial dysplasia. Endoscopy 1993; 25: $261-264$

${ }^{162}$ Hallissey MT, Allum WH, Jewkes AJ, et al. Early detection of gastric cancer. Brit Med J 1990; 301: 513-515

${ }^{163}$ Caprilli R, Andreoli A. Capurso L, et al. Oral mesalazine (5aminosalicylic acid; Asacol) for the prevention of post-operative recurrence of Crohn's disease. Gruppo Italiano per lo Studio del Colon e del Retto (GISC). Alimentary Pharmacology \& Therapeutics 1994: $8: 35-43$

${ }^{104}$ Iwao T, Toyonaga A, Ikegami M, et al. McCormack's endoscopic signs for diagnosing portal hypertension: comparison with gastroesophageal varices. Gastrointest Endose 1994; 40: $470-473$

${ }^{165}$ Ziegler K, Sanft C, Zimmer T, et al, Comparison of computed tomography, endosonography, and intraoperative assessment in In staging of gastric carcinoma. Gut 1993; 34: 604-610

${ }^{166}$ Dittler HJ. Siewert JR. Role of endoscopic ultrasonography in gastric carcinoma. Endoscopy 1993; 25: 162-166

${ }^{167}$ Grimm H, Binmoeller KF, Hamper K, et al. Endosonography for preoperative locoregional staging of esophageal and gastric cancer. Endoscopy $1993 ; 25: 224-230$

\section{Corresponding Author}

Florian Froehlich, MD, PD

Policlinique Médicale Universitaire

Rue César-Roux 19

CH-1005 Lausanne

Switzerland

Fax: $\quad+41-32-4662955$

E-mail: florian.froehlich@bluewin.ch 